\title{
Correction to: Exploring determinants of financial system and environmental quality in high-income developed countries of the world: the demonstration of robust penal data estimation techniques
}

\author{
Muhammad Zeeshan ${ }^{1}$ (D) Jiabin Han ${ }^{1} \cdot$ Alam Rehman $^{2} \cdot$ Irfan Ullah ${ }^{3} \cdot$ Fakhr E Alam Afridi ${ }^{4}$ \\ Published online: 22 July 2021 \\ (C) Springer-Verlag GmbH Germany, part of Springer Nature 2021
}

\section{Correction to: Environmental Science and Pollution Research https://doi.org/10.1007/s11356-021-15105-9}

The article Exploring determinants of financial system and environmental quality in high-income developed countries of the world: the demonstration of robust penal data estimation techniques by Muhammad Zeeshan, Jiabin Han, Alam Rehman, Irfan Ullah and Fakhr E Alam Afridi, was originally published online on 29 June 2021 with Open Access under a Creative Commons Attribution 4.0 International License, which permits use, sharing, adaptation, distribution and reproduction in any medium or format, as long as you give appropriate credit to the original author(s) and the source, provide a link to the Creative Commons license, and indicate if changes were made. The images or other third party material in this article are included in the article's Creative Commons license, unless indicated otherwise in a credit line to the material. If material is not included in the article's Creative Commons license and your intended use is not permitted by statutory

regulation or exceeds the permitted use, you will need to obtain permission directly from the copyright holder. To view a copy of this license, visit http://creativecommons. org/licenses/by/4.0.

With the author's/authors' decision to cancel Open Access the copyright of the article changed on 3 July 2021 to $@$ SpringerVerlag GmbH Germany, part of Springer Nature 2021 with all rights reserved.

The Original article has been corrected.

The online version of the original article can be found at https://doi.org/10.1007/s11356-021-15105-9

Publisher's note Springer Nature remains neutral with regard to jurisdictional claims in published maps and institutional affiliations.

The online version of the original article can be found at https://oi.org/ 10.1007/s11356-021-15105-9

Muhammad Zeeshan

shanzeelntu1922@gmail.com

Fakhr E Alam Afridi

falaam89@gmail.com

Jiabin Han

271339003@qq.com

Alam Rehman

amrehman@numl.edu.pk

Irfan Ullah

irfanecon@nuist.edu.cn

College of Business Administration, Liaoning Technical University, Xingcheng 125105, Liaoning Province, China

2 Faculty of Management Sciences, National University of Modern Languages, Islamabad, Pakistan

3 Reading Academy, Nanjing University of Information Science and Technology, Nanjing, People's Republic of China

4 Islamia College Peshawar, Peshawar, Pakistan 